\title{
Critical Success Factors of Product Development Projects in the Automotive Industry
}

\author{
Oberti Almeida ${ }^{1}$, Paulo S. Figueiredo ${ }^{2 *}$, Valter Estevão Beal ${ }^{1}$, Francisco Uchoa Passos ${ }^{1}$
}

\begin{abstract}
The objective of this study was to determine the critical success factors (CSFs), as well as respective best practices (BPs) associated with those factors, using a case survey of the employees of Ford Motor Company working in different development centers around the world. The company's project managers were asked to respond to two structured questionnaires. The results confirm the study's assumption that the order of importance of the CSFs of the automotive industry differ from those of other industries in general. The results also reflect the importance of the front end (FE) phase in the new product development process. Regional differences were also observed. Neglecting CSFs can lead to delayed decision-making, resulting in higher development costs or cancellations of projects.
\end{abstract}

Keywords: project management; front-end in product development; critical success factors; product development; automotive Industry.

Submitted: January $6^{\text {th }}, 2020 /$ Approved: August $25^{\text {th }}, 2020$

\section{Introduction}

New product development is full of uncertainty, and it often involves new technologies and processes. It is not in the interest of any company to launch defective products or cancel them before they are even launched (Repenning, Gonçalves \& Black, 2001).

The automotive industry, like other industrial sectors, is negatively affected by the cancellation of projects that are still in the product development (PD) phase. The cancellation of a project during the $\mathrm{PD}$ phase leads to lost resources, competitive disadvantages due to not launching a new or modified product in the market, and general financial losses. The causes are diverse and highly complex, and addressing them requires extensive efforts from the project manager. The literature largely addresses why projects fail to deliver what is expected. There is a consensus among researchers that some critical success factors (CSFs) significantly impact the success of a project under development for most industrial sectors (Pinto \& Slevin, 1988, Müller \& Jugdev, 2012). However, each industrial sector has its own characteristics, which motivates studies on determining these causes in specific industries and finding evidence of their importance.

There are questions about why so many projects fail to deliver their objectives despite using project management practices. Obviously, using these practices does not ensure a project's success nor does their absence ensure the project's failure. Understanding the operative critical factors is important for project managers since it will allow them to know what to look for when managing their projects (Dinu, 2016).

Almost one in three projects fails to deliver as expected due to diverse causes. This result was found in a study of organizations from eight different industries: defense, engineering, mining, telecommunications, aerospace, information technology, automotive, and medical (Buys \& Stander, 2010).
It is common knowledge that the practices and decisions that are implemented in the phases prior to PD may result in a project's subsequent cancellation. If project managers are not aware of the critical factors that can influence their objectives in the initial phase, then the project is unlikely to succeed (Alias, Zawawi, Yusof \& Aris, 2014).

Many studies have been conducted to determine the CSFs (e.g., Pinto \& Slevin, 1988; Alias et al., 2014; Chan et al., 2004) in different industries in order to minimize the problems. However, the new product development process in each industry is different with different configurations and conditions. An approach that is focused on a specific industrial sector has the potential to elucidate the factors that are most important in this specific context since some factors undoubtedly predominate over others.

This results the following research question: "What are the critical success factors for new product development projects in the automotive industry?"

The study object is Ford Motor Company, a multinational automotive company that has different product development (PD) centers around the world with a manufacturing presence on all continents. Its primary PD center is located in the United States.

This study's assumption is that the most important CSFs for projects in the automotive industry differ from the CSFs for projects in other industries in general due to the specific characteristics of the product and business in question. Supporting this assumption is the fact that the success or failure of a project can be determined by many factors, which are beyond the control of management (Belassi \& Tukel, 1996).

In regard to the new product development (NPD) process, the question becomes even more complex due to higher expenditures and the extent to which the clients' preferences become more multifaceted and

(1) Centro Universitário SENAI CIMATEC - Piatã, Salvador- BA, Brazil.

(2) Escola de Administração da UFBA, BA, Brazil.

*Corresponding author: paulo_s_figueiredo@hotmail.com 
changing, which requires rapid adjustments and novel ideas (Clark \& Wheelwright, 1993; Bahia \& Domingues, 2010; Roy, Colmer, Griggs \& ROY, 2005).

\section{Theoretical Framework}

This section is divided in two topics, namely critical success factors (CSF) in project management and Best Practices Associated with CSFs.

\subsection{CSFs in Project Management}

CSFs are referenced in the literature as factors that can determine a project's success or failure and are beyond the conventional control of project management. Studies that evaluate, explain or analyze these factors are still lacking (Belassi \& Tukel, 1996).

Milosevic and Patanakul (2005), in their study of projects in the electronics, computer and software industries, reported that, from the viewpoint of project management, CSFs can be defined as conditions, characteristics or variables that have significant impacts on a project and can result in project success when properly maintained, managed and sustained.

The search to understand and use CSFs has been established and popularized over the last 20 years (Chan et al., 2004). Despite the different studies on identifying CSFs, there is no consensus among researchers regarding the factors that influence project success (Fortune \& White, 2006).

Alias et al. (2014), in their study of civil construction projects, report that in the context of known problems in project management, CSFs emerge as decision-making supports. Considering an "input-processing-output" model, CSFs are the inputs for project management that can directly or indirectly lead to project success.

Many studies have shown that NPD projects, regardless of the type of organization, succeed or fail due to similar reasons. Researchers have thus sought to identify these reasons. The answers typically include factors such as project missions, communication, policies, planning, control, and top management support. However, despite their popularity, few organizations or managers have actually used CSFs to improve their management processes (Sauser, Reilly \& Shenhar, 2009). Rockart (1982), in his study of nine large and important information systems companies, found direct effects for three CSFs: communication, human resources, and the constant adaptation to new processes and technologies. The executives at these companies began to be seen as "thinkers," "planners" and "coordinators" rather than direct "implementers" and "doers." In these cases, these executives were focused on helping their organizations adapt to a changing environment.
Pinto and Slevin (1988), with the aim of helping project managers gain a clear view of CSFs, conducted an empirical study using a sample of 159 PD projects, including new product development, software and hardware, food and drugs, among others. As a result, a ten-factor model was established that included the items or activities that are critical for project success. The authors report that knowing when these CSFs will impact a project's development is as important as knowing the CSFs.

The interrelationship of CSFs in project management is of such importance that no single factor is responsible for ensuring a project's success. They are all interdependent and require a holistic approach (Clarke, 1999).

On this subject, Fortune and White (2006) note that the interrelationships between CSFs are at least as important as the individual CSFs. Based on the above studies, this study proposes a simple conceptual model (Figure 1) that establishes the interrelationships between CSFs in projects with the three key performance dimensions within the context of project management (costs, time and quality). This allows one to explore the effects of CSFs on the potential failure or cancellation of a project.

The conceptual model suggests that by considering the CSFs in the three performance dimensions, a project is less likely to be discontinued.

Figure 1. Conceptual model

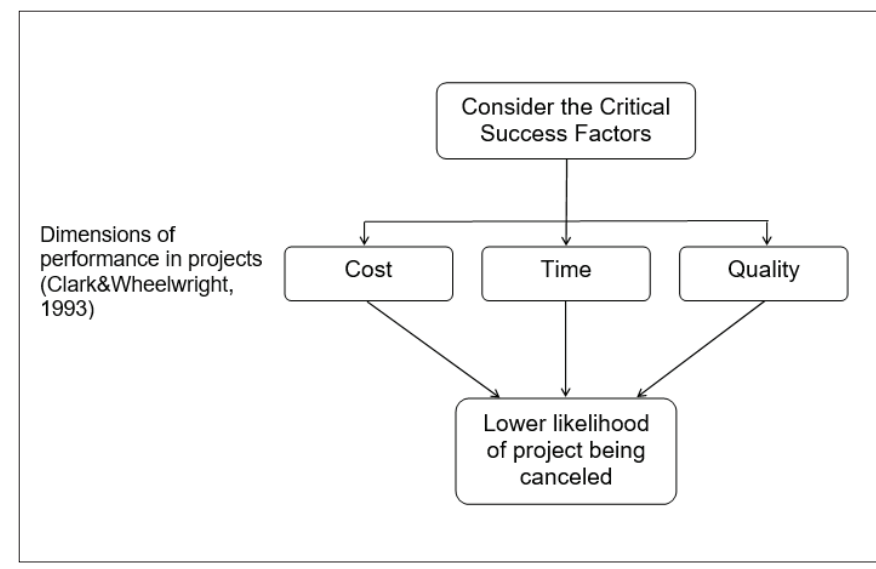

Source: the author

The CSFs that are cited in the reviewed literature were classified into six categories, which were used in the survey: communication, strategy, management, planning, processes, and human resources. A cause and effect diagram was used to illustrate these categories. 
Figure 2. CSF cause and effect diagram

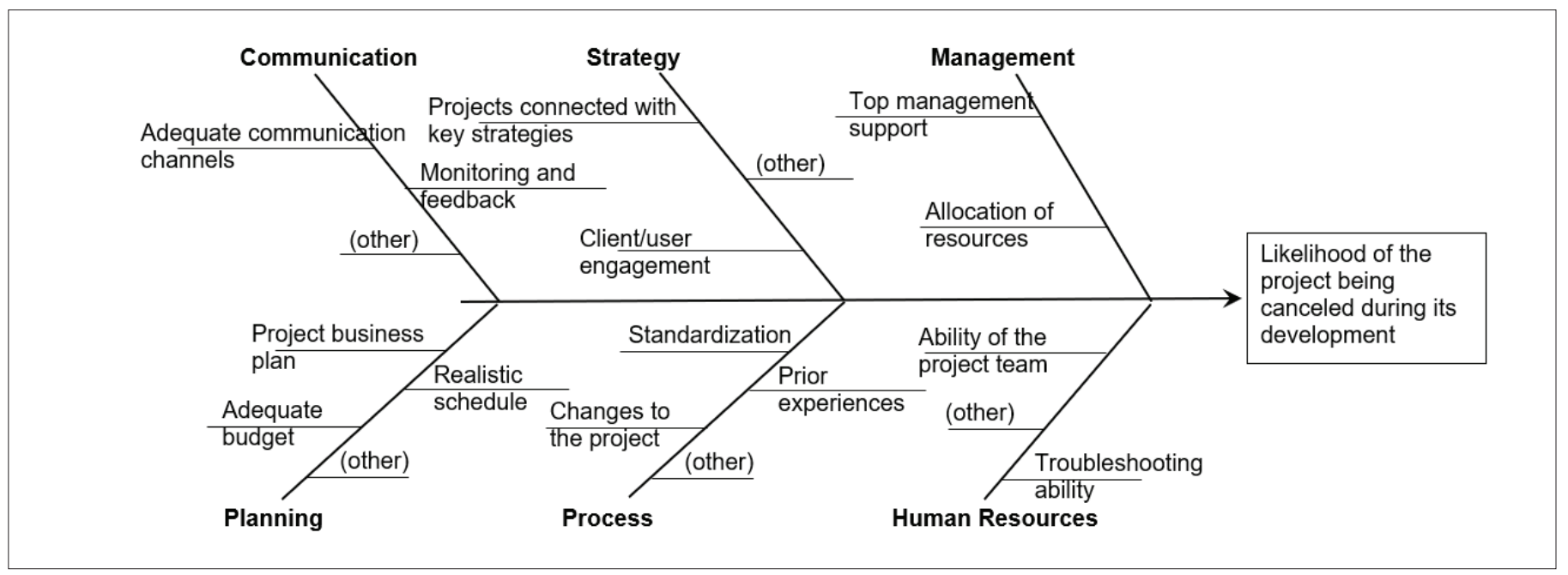

Source: the author

Table 1 presents these CSFs that were identified in 44 publications in the reviewed literature. In the table, the CSFs are organized within each category in descending order of the numbers of citations that were found. Brief descriptions or explanations of some of the factors are not presented here, for brevity. However they were presented to the respondents. The six most cited factors in the 44 publications are the following:

- Top management support;

- Client/user engagement;

- The availability of a skilled/appropriately qualified/sufficient team;
- Adequate communication channels;

- The adequate targeting, assessment, and management of risks; and - Effective monitoring/control.

These six factors are contained in four categories: communication, strategy, management, and human resources. Although $62 \%$ of the publications cite at least one of these six factors, only $3 \%$ of them include all six factors. Given this finding, there is clearly a limited consensus among researchers regarding the most important CSFs for projects in the NPD process.

Table 1. The CSFs that were identified in 44 publications

\begin{tabular}{|c|c|c|c|}
\hline Category & Critical success factors for projects & Author(s) & \# of citations \\
\hline \multirow{7}{*}{ 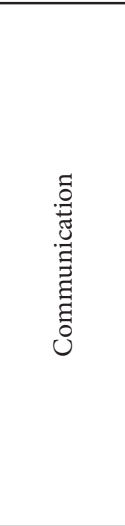 } & Adequate communication channels & $\begin{array}{l}\text { Pozin et al. (2016); Lindhard and Larsen(2016); Turner (2004); Wester- } \\
\text { veld (2003); Frese and Sauter (2003); Cooke-Davies (2002). Yeo (2002); } \\
\text { Chan et al.(2004); Thite (2000); Turner (1999) }\end{array}$ & 10 \\
\hline & Appropriate client consultation & Frese and Sauter (2003); Pinto and Slevin (1988) & 2 \\
\hline & Consideration of different viewpoints & Turner (2004); Pinto and Kharbanda (1995) & 2 \\
\hline & $\begin{array}{l}\text { Appropriate coordination in the flow of data between the } \\
\text { information system and the organizational processes }\end{array}$ & Gal and Hadas (2015) & 1 \\
\hline & $\begin{array}{l}\text { Provision of an appropriate network and necessary data } \\
\text { for all participants }\end{array}$ & Pinto and Slevin (1988) & 1 \\
\hline & Availability of a two-way channel: & Rockart (1982) & 1 \\
\hline & $\begin{array}{l}\text { Availability of a standardized information system for } \\
\text { project management }\end{array}$ & Milosevic and Patanakul (2005) & 1 \\
\hline \multirow{4}{*}{ 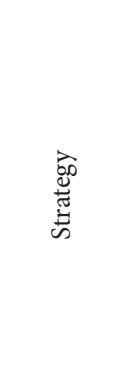 } & $\begin{array}{l}\text { Clear connection between projects and the company's } \\
\text { key strategic priorities }\end{array}$ & Stanley and Uden (2013) & 1 \\
\hline & Projects connected to the company's strategic objective & Buys and Stander (2010) & 1 \\
\hline & Realistic expectations & Frese and Sauter (2003) & 1 \\
\hline & $\begin{array}{l}\text { Project mission: initial clarity of objectives and general } \\
\text { directions }\end{array}$ & Pinto and Slevin (1988) & 1 \\
\hline
\end{tabular}

ISSN: 0718-2724. (http://jotmi.org) 


\begin{tabular}{|c|c|c|c|}
\hline \multirow[t]{2}{*}{ 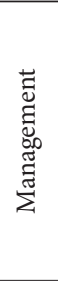 } & Top management support & $\begin{array}{l}\text { Dupont and Eskerod (2016); Stanley and Uden (2013); Turner (2004); } \\
\text { Cooper and Kleinschmidt (2007); Frese and Sauter (2003); Westerveld } \\
\text { (2003); Yeo (2002); Cooke-Davies (2002); Poon and Wagner (2001); Thi- } \\
\text { te (2000); Turner (1999); Whittaker (1999); Dvir et al. (1998); Belassi and } \\
\text { Tukel (1996); Munns and Bjeirmi (1996); Cash and Fox (1992); Hughes } \\
\text { (1986); Pinto and Slevin (1988) }\end{array}$ & 18 \\
\hline & $\begin{array}{l}\text { Appropriate targeting of risks, access and management } \\
\text { of risks }\end{array}$ & $\begin{array}{l}\text { Dinu (2016); Carvalho and Rabechini (2015); Westerveld (2003); Yeo } \\
\text { (2002); Cooke-Davies (2002); Weir (1999); Whittaker (1999); Dvir et al. } \\
\text { (1998); Baldry (1998) }\end{array}$ & 10 \\
\hline \multirow{13}{*}{ 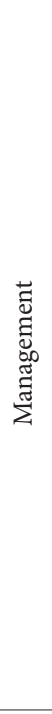 } & Effective monitoring/control & $\begin{array}{l}\text { Turner (2004); Westerveld (2003); Cooke-Davis (2002); Poon and Wagner } \\
\text { (2001); Chan et al. (2001); Chua et al. (1999); Thite (2000); Weir (1999) }\end{array}$ & 8 \\
\hline & Good leadership & $\begin{array}{l}\text { Turner (2004); Westerveld (2003); Thite (2000); Turner (1999); Clark and } \\
\text { Wheelwright (1993) }\end{array}$ & 5 \\
\hline & Consider both opportunities and threats & Dinu $(2016)$ & 1 \\
\hline & Effective engagement from stakeholders & Stanley and Uden (2013) & 1 \\
\hline & $\begin{array}{l}\text { Due separation between daily work activities and stra- } \\
\text { tegic activities }\end{array}$ & Buys and Stander (2010) & 1 \\
\hline & $\begin{array}{l}\text { Does not change the project's priorities frequently, with } \\
\text { a reallocation of resources }\end{array}$ & Buys and Stander (2010) & 1 \\
\hline & Sufficient allocation of resources & Frese and Sauter (2003) & 1 \\
\hline & Use of proven project and risk management methods & Stanley and Uden (2013) & 1 \\
\hline & Availability of required technology and specialization & Pinto and Slevin (1988) & 1 \\
\hline & $\begin{array}{l}\text { Effective canceling of projects that have an inadequate } \\
\text { concept before they reach the project phases }\end{array}$ & Repenning et al. (2001) & 1 \\
\hline & $\begin{array}{l}\text { Revise the product plan when a project encounters pro- } \\
\text { blems, even in advanced phases of development }\end{array}$ & Repenning et al. (2001) & 1 \\
\hline & Attraction and retention of talented people & Rockart (1982) & 1 \\
\hline & $\begin{array}{l}\text { Balanced availability of resources (people) versus num- } \\
\text { ber of active projects }\end{array}$ & Buys and Stander (2010) & 1 \\
\hline \multirow{10}{*}{ 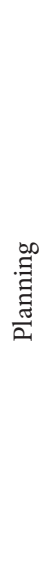 } & $\begin{array}{l}\text { Establish a strong business plan/solid foundation for } \\
\text { the project }\end{array}$ & $\begin{array}{l}\text { Turner (2004); Westerveld (2003); Cooke-Davis (2002); Yeo (2002); Poon } \\
\text { and Wagner (2001); Munns and Bjeirmi (1996); Pinto and Kharbanda (1996) }\end{array}$ & 7 \\
\hline & Realistic schedule & $\begin{array}{l}\text { Turner (2004); Westerveld (2003); Yeo (2002); Turner (1999); Dvir et al. } \\
\text { (1998); Kasser and Williams (1998) }\end{array}$ & 6 \\
\hline & Sufficient/good resources allocated & $\begin{array}{l}\text { Cooper and Kleinschmidt (2007); Turner (2004); Westerveld (2003); } \\
\text { Turner (1999); Dvir et al. (1998); Kasser and Williams (1998) }\end{array}$ & 6 \\
\hline & $\begin{array}{l}\text { Adequate planning if it is necessary to end the project, } \\
\text { or revise it, due to potential failure }\end{array}$ & $\begin{array}{l}\text { Pinto and Kharbanda (1996); Dvir et al. (1998); Munns and Bjeirmi } \\
\text { (1996); Beare (1995) }\end{array}$ & 4 \\
\hline & Adequate budget & Turner (2004); Westerveld (2003); Chan et al. (2001); Baker et al. (1983) & 4 \\
\hline & Provide adequate training for the project teams & Dvir et al. (1998); Pinto and Kharbanda (1996); Pinto and Kharbanda (1995) & 3 \\
\hline & Appropriate planning procedures & Frese and Sauter (2003) & 1 \\
\hline & $\begin{array}{l}\text { Appropriate planning and implementation of actions to } \\
\text { contain project risks }\end{array}$ & Dinu (2016) & 1 \\
\hline & Resource planning & Repenning (2001) & 1 \\
\hline & Clear description of project requirements & Frese and Sauter (2003) & 1 \\
\hline \multirow{9}{*}{ 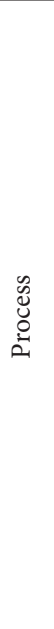 } & Effective management of project changes & $\begin{array}{l}\text { Yeo (2002); Cooke-Davis (2002); Poon and Wagner (2001); Thite (2000); } \\
\text { Dvir et al. (1998); Weir (1999); Cash and Fox (1992) }\end{array}$ & 7 \\
\hline & $\begin{array}{l}\text { Correct choice/past experience of project management } \\
\text { methodologies/tools }\end{array}$ & $\begin{array}{l}\text { Turner (2004); Dvir et al. (1998); Munns and Bjeirmi (1996); Hughes } \\
\text { (1986) }\end{array}$ & 4 \\
\hline & $\begin{array}{l}\text { Learning and use of past experience (learned from pre- } \\
\text { vious projects) }\end{array}$ & $\begin{array}{l}\text { Lindhard and Larsen(2016); Cooke-Davis (2002); Dvir et al. (1998); Jor- } \\
\text { dan et al. (1988) }\end{array}$ & 4 \\
\hline & Use of proven/familiar technology & Yeo (2002); Poon and Wagner (2001); Dvir et al. (1998) & 3 \\
\hline & $\begin{array}{l}\text { Effective and adequate organizational/cultural/structu- } \\
\text { ral adaptation }\end{array}$ & Cooke-Davis (2002); Thite (2000) & 2 \\
\hline & Existence of appropriate ethical standards for projects & Gal and Hadas (2015) & 1 \\
\hline & $\begin{array}{l}\text { Availability of appropriate standards for tools, proces- } \\
\text { ses and metrics }\end{array}$ & Milosevic and Patanakul (2005) & 1 \\
\hline & $\begin{array}{l}\text { Availability of appropriate standards for leadership, or- } \\
\text { ganization and cultural aspects }\end{array}$ & Milosevic and Patanakul (2005) & 1 \\
\hline & $\begin{array}{l}\text { Appropriate clarification of the responsible for pro- } \\
\text { blems related to the project }\end{array}$ & Dinu (2016) & 1 \\
\hline
\end{tabular}




\begin{tabular}{|c|c|c|c|}
\hline \multirow{11}{*}{ 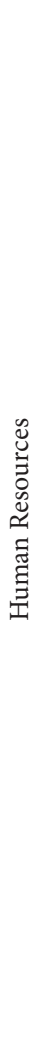 } & Existence of a skilled/appropriately qualified/sufficient team & $\begin{array}{l}\text { Cooper and Kleinschmidt (2007); Westerveld (2003); Cooke-Davis } \\
\text { (2002); Poon and Wagner (2001); Dvir et al. (1998); Weir (1999); Frese } \\
\text { and Sauter (2003); Chua et al. (1999); Cash and Fox (1992); Pinto and } \\
\text { Slevin (1988); Baker et al. (1997) }\end{array}$ & 11 \\
\hline & Have a competent project manager & Frese and Sauter (2003); Chan et al.(2001); Pinto and Slevin (1988) & 3 \\
\hline & Good motivation from the project team & Chua et al. (1999); PMBOK (2013) & 2 \\
\hline & $\begin{array}{l}\text { Compensate project participants as generously as they } \\
\text { believe is adequate }\end{array}$ & Gal and Hadas (2015) & 1 \\
\hline & Availability of an adequate trouble-shooting process & Frese and Sauter (2003) & 1 \\
\hline & $\begin{array}{l}\text { Participants significantly influencing how the operatio- } \\
\text { nal system functions and performs }\end{array}$ & Gino and Pisano (2008) & 1 \\
\hline & Troubleshooting & Pinto and Slevin (1988) & 1 \\
\hline & $\begin{array}{l}\text { Not compensating members of the team only for being } \\
\text { good at "putting out fires" }\end{array}$ & Repenning et al.(2001) & 1 \\
\hline & Appropriate engagement from the entire project team & Chua et al. (1999) & 1 \\
\hline & Project team is skilled at measuring changes over time & PMBOK (2013) & 1 \\
\hline & $\begin{array}{l}\text { Project team is skilled at dealing with the demand of } \\
\text { project activities or tasks }\end{array}$ & PMBOK (2013) & 1 \\
\hline
\end{tabular}

\subsection{Best Practices Associated with CSFs for the Front End (FE) Phase} Once the six most important CSFs for NPD were defined in the sample (first phase of the study), the next step was to identify the BPs that are associated with these CSFs, based on the relevant literature. Table 2 presents a list of $31 \mathrm{BPs}$ that are associated with the six most important
CSFs that are defined in the first phase. These BPs were identified in 24 publications in the studied literature. The questionnaire that surveys the BPs was then constructed and administered to the sample of project managers, constituting the second phase of the study.

Table 2. BPs associated with the most important CSFs

\begin{tabular}{|c|c|c|}
\hline 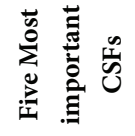 & Best practices & Author(s) \\
\hline \multirow{3}{*}{ 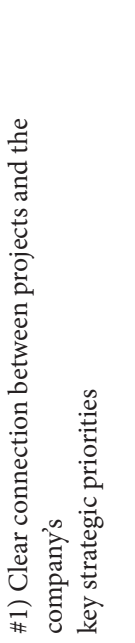 } & $\begin{array}{l}\text { - There are new product goals for the business unit, and the focus areas are outlined. The role of the new pro- } \\
\text { ducts is clearly communicated and there is long-term confidence. } \\
\text { - There are clearly defined areas of strategic focus, strategic areas, to steer the company's new product. } \\
\text { - There are goals or objectives for the company's new product (for example: sales, profit). } \\
\text { - Establish direct links between product decisions and the business strategy. } \\
\text { - Considering the general business justification, consider questions related to product distribution as part of } \\
\text { the product's definition. }\end{array}$ & $\begin{array}{l}\text { Cooper and Kleinschmidt } \\
\text { (2007) }\end{array}$ \\
\hline & $\begin{array}{l}\text { - Use of a requirements traceability matrix to ensure that each requirement adds business value through its } \\
\text { link to the business objectives and the project objectives. }\end{array}$ & $\begin{array}{l}\text { Desmond (2017); PMBOK } \\
\text { (2013) }\end{array}$ \\
\hline & $\begin{array}{l}\text { - The project should solve a defined business problem or meet a need that can be effectively addressed with } \\
\text { product technology. }\end{array}$ & $\begin{array}{l}\text { Pinto and Kharbanda } \\
\text { (1996) }\end{array}$ \\
\hline
\end{tabular}




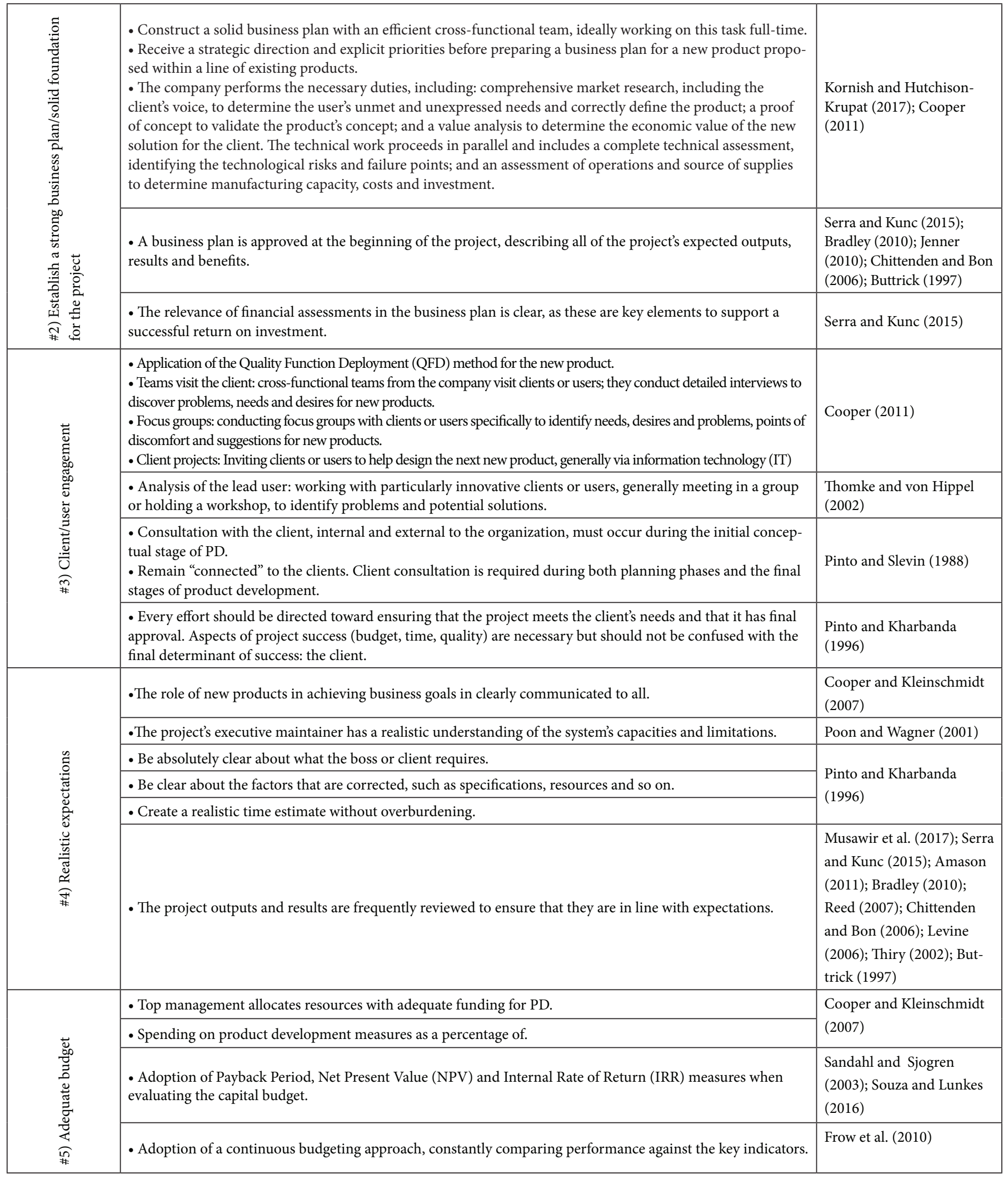




\section{Method}

This study was carried out within the context of PD in the automotive industry and addressed project management and its respective challenges to achieving success. The unit of analysis is new vehicle projects, including both platform and derivative projects (Clark \& Wheelwright, 1993). Given the different understandings of project "success", for the purposes of this study, success is defined as the project not being canceled during the PD phase.

To achieve the objectives, an exploratory qualitative and quantitative empirical study was conducted. The study included remote responses to an online structured questionnaire. The sample included project managers at different levels and in different units of a single multinational automotive company; therefore, the case study survey adopted a nonprobability convenience sample. With regard to the objectives, this is an explanatory study (Gil, 2008) since it seeks to identify the factors that determine or contribute to the occurrence of phenomena, which, in this case, are the CSFs of projects and their respective associated BPs.

The review of the literature on CSFs and associated BPs was performed by searching the following databases: Google Scholar, EBSCO/ Business Source Premier, Pro-Quest/ABI, and Science Direct. The searches occurred from February to April 2018 for CSFs and from November to December 2018 for BPs. The search criteria were keywords that were present in the title or abstract of the articles with available full versions. The keywords that were used to search for articles related to CSFs were the following: "Critical factors", "Project success", and "Product development." The keywords that were used to search for articles referring to BPs were the following: "Best practices" and "Project management." The study's inclusion criteria were as follows: full scientific articles that were published in Portuguese and English from 1990 to 2018 and addressed the issue of CSFs for industrial NPD projects in general. Literature reviews and papers that were published before 1990 were excluded. The abstracts of the articles that passed the above filters were analyzed, and then the articles that met the selection criteria were read in full. In total, 44 publications met the selection criteria for CSFs, and 24 publications met the selection criteria for BPs.

The study sample includes the project managers/executives at the aforementioned company who work on all continents where the company has R\&D centers, namely South America, North America, Europe, Asia, and Oceania. These people may be referred to as "respondents" in the remainder of this paper. The number of managers in South America was significantly higher than those on other continents due to the easier interaction. The questionnaires were administered in the following sequential order in two phases:

1) Questionnaires to define the five most important CSFs, and

2) Questionnaires to define the BPs that are associated with those five CSFs.
Some respondents may have answered the two questionnaires in this order, but this was not a mandatory requirement of the study. Similarly, a respondent may have answered only one of the questionnaires. The total sample size was 91 respondents, representing approximately $9 \%$ of the total population.

The sample characteristics for the first questionnaire for CSFs were as follows:

- $\quad$ total sample size $=98$,

- total number of respondents $=70$, and

- $\quad$ response rate $=71.4 \%$.

The sample characteristics for the second questionnaire for BPs were the following:

- $\quad$ total sample size $=45$,

- $\quad$ total number of respondents $=31$, and

- $\quad$ response rate $=68.8 \%$.

The main research instruments are two structured questionnaires that were hosted on the Google Forms online platform. The study thus had two data collection phases. In the first phase, the first questionnaire asked about the five most important CSFs according to each respondent based on the set of 82 CSFs that were found in the 44 publications. A redundancy-focused analysis was performed on the descriptions of the 82 CSFs to group the repeated CSFs or those with strong similarity to others, thus resulting in $64 \mathrm{CSF}$ on the final questionnaire. The instrument was designed to limit the selection to at most five CSFs per respondent; however, it did not prevent the respondent from selecting a smaller number.

The questionnaire for BPs was designed to limit the selection to only one BP being associated with each of the five CSFs that were selected on the first questionnaire.

Both questionnaires were pretested on a group of 12 engineers working in NPD in the automotive industry, including people from all the regions where the questionnaire was administered, in order to test the response time, the comprehension of the questions, and gather feedback to improve the questions. Some small adjustments were made.

\section{Results and Discussion}

This section presents the results. The data will be discussed by focusing on the five most important CSFs in the opinion of the respondents, as well as the respective BPs that are associated with those CSFs.

\subsection{Results and discussion of the CSF questionnaire}

Figure 3 presents the locations of the respondents. The majority of them (50.7\%) work in South America.

The fact that the vast majority of the respondents are located in South America is explained by two main reasons: most of the requests were 
directed to project managers that were located in that region, and the author works in the automotive industry in that region. The response rates of the other regions were satisfactory, considering the geographical distances and level of contact between the author and the respondents.

With regard to the respondents' hierarchical leadership levels, the following alternatives were created: Top Executive/Chief Executive Officer (CEO)/President/Chief Operating Officer, Director/Department Chief, Area Manager/Area Administrator, and Supervisor/Team Leader. Figure 4 presents the stratification of the sample by level.

Figure 3. Geographic locations of respondents

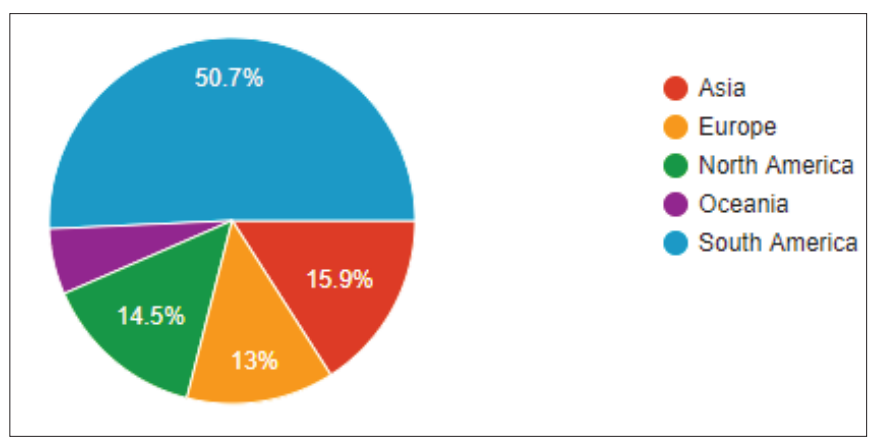

Figure 4. Hierarchical leadership levels of respondents

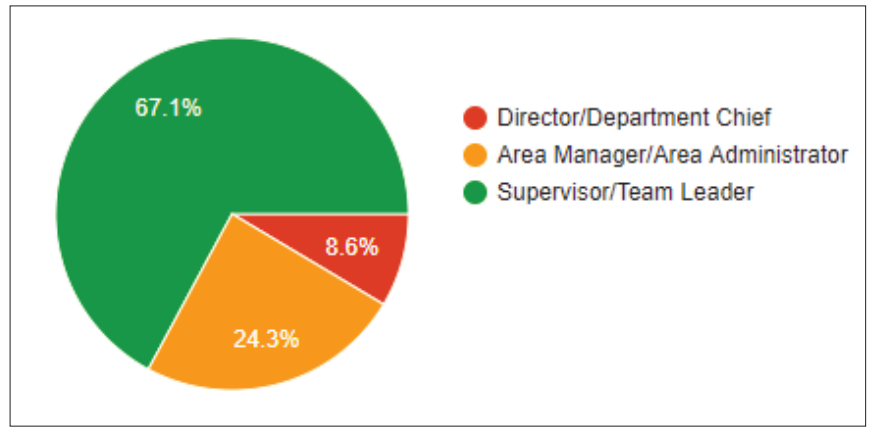

Although a large number (43.5\%) have been in their current leadership position for less than 5 years, most respondents (44.3\%) have more than 20 years of experience. The respondents therefore have a high level of experience. The "male" gender predominates with $80.9 \%$ of the respondents.

When asked to estimate the percentage of canceled projects during the period in which the respondent had held their current leadership position, most of the respondents (35.7\%) estimate a rate between 11 to $30 \%$. This rate is similar to the usual rate of NPD projects that fail to achieve industry success, which is $33.3 \%$ (Buys \& Stander, 2010). However, a significant proportion of the respondents (27.1\%) estimate an even higher rate of between 31 and 50\%, indicating that the rate of canceled NPD projects at the company under study is higher than that of industry in general.

With regard to the five most important CSFs according to the respondents, of the 64 CSFs that were listed in the questionnaire, the five
CSFs that were most frequently selected by the respondents were, in descending order, the following:

- Clear connection between projects and the company's key strategic priorities,

- Establish a strong business plan/solid foundation for the project,

- Client/user engagement,

- Realistic expectations, and

- $\quad$ Adequate budget.

Among the five CSFs most frequently that were selected by the respondents, there are clearly two distinct groups in terms of how frequently they were selected on the questionnaire: the first group was formed by the two most frequently selected CSFs, which received more than twenty votes; and the second group included the other three CSFs, with between fourteen and sixteen votes.

The five CSFs belong to only two of the six categories that defined, which are strategy and planning. This differs from the reviewed literature in which the five most frequently cited CSFs belong to four distinct categories. Only one CSF, "client/user engagement," and one category, "strategy," are common between the results of the questionnaire and the reviewed literature.

The five most important CSFs alone represent 29\% of the total responses. The results show that there is a clear convergence of the respondents' opinions regarding the importance of strategy and planning in the NPD process.

With regard to the importance of CSF number 1, "Clear connection between projects and the company's key strategic priorities," a project that clearly demonstrates its benefits by being connected to the business's objectives will be easily "sold" and accepted (Poom \& Wagner, 2001). Many stakeholders often disagree in order to achieve their own interests or objectives, which they themselves have created for their own working group, rather than focusing on achieving the objectives of the company as a whole (Stanley \& Uden, 2013).

With regard to the importance of CSF number 2, "Establish a strong business plan/solid foundation for the project," a project only receives approval to proceed-at the approval meetings of the stages of the NPD process-with a strong business plan containing all the decision elements. The project manager defines the success criteria and is responsible for managing the project. All the decision elements must be contained in the business plan (Turner, 2004).

With regard to the importance of CSF number 3, "Client/user engagement," the current clients want to interact with the companies in order to cocreate their experiences and products. Interaction is the foundation for creating value (Stanley \& Uden, 2013). All clients/users need to be consulted and updated on the project's status. Project team members share the information that is requested by all potential clients/users (Frese \& Sauter, 2003). 
Regarding the importance of CSF number 4, "Realistic expectations," critical to the project's success is the ability of the project's champion (or maintainer) to clearly communicate the project's objectives to managers in order to meet the expectations of the top management and clients (Belassi \& Tukel, 1996). The importance of clear objectives, including project deliverables and scope, is sometimes neglected. The objectives and scope are essential in guiding the project team to success. Although these two elements are often addressed separately, there are good reasons to group them since, without a well-defined scope, the project's objectives can become confusing for the project team (Clarke, 1999).

Regarding the importance of CSF number 5, "adequate budget," it is necessary to understand that a budget is primarily a project manage- ment item rather than a project objective (Munns \& Bjeirmi, 1996). The finance department must agree on the estimated budget for a new project. As the work begins, project changes require higher costs, and a change to one system impacts another system. Delays are inevitable and result in high costs and reduced benefits (Turner, 2004). Establishing a good budget at the beginning of the project will prevent competing priorities in terms of manpower and financial resources (Dinu, 2016).

All five of the most important CSFs are part of the FE phase, as presented in Figure 5. This figure shows the CSFs resulting from the study and the activities in the FE phase side by side. This confirms what is found in the literature, which argues that this is the most important phase of the NPD process.

Figure 5. CSFs integrated into activities in the FE phase

\begin{tabular}{c} 
Five most important CSFs \\
(Results of the questionnaire) \\
\hline $\begin{array}{c}\text { Clear connection between projects and the } \\
\text { company's key strategic priorities }\end{array}$ \\
\hline $\begin{array}{c}\text { Establish a strong business plan/solid } \\
\text { foundation for the project }\end{array}$ \\
\hline Client/user engagement \\
\hline
\end{tabular}

Realistic expectations

Adequate budget

Regarding the impact of the CSFs on the three dimensions of project performance (costs, quality, and time), in the respondents' opinions, there was a unanimous consensus across the sample that the CSFs impact the three key dimensions of project performance. These results confirm the importance of the CSFs for projects that are implemented at the company under study and agree with industry in general according to the relevant literature and with the conceptual model that was proposed in the study.
Activities in the FE phase (studied literature)

Connection between business strategy and NPD

Financial impact

Identification of the clients' needs

Level of performance desired

Specification of the resources needed to complete the project

Regarding the level of impact of the CSFs on the three dimensions of project performance (costs, quality, and time), Figure 6 presents the results. For each performance criterion, the numbers of times that respondents indicated that the criterion was the most important, $2^{\text {nd }}$ most important, and $3^{\text {rd }}$ most important are presented. The following order was obtained.

Figure 6. Level of impact on the dimensions of project performance

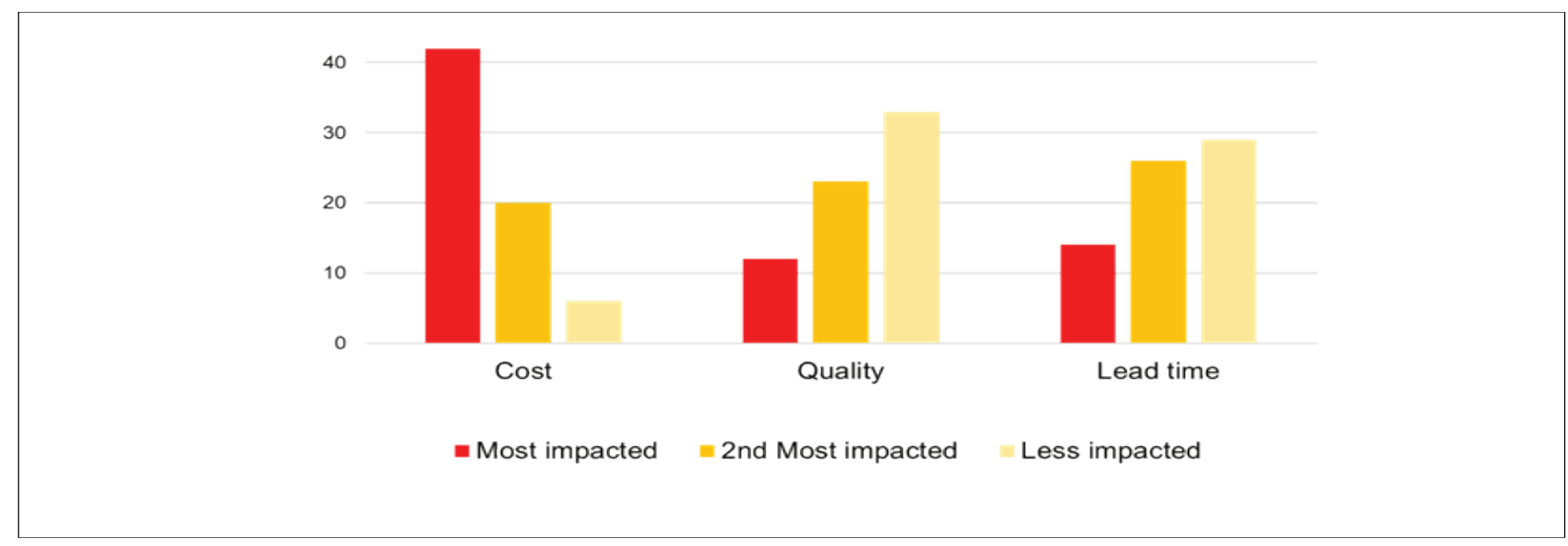

ISSN: 0718-2724. (http://jotmi.org) 
Given the results that are obtained, there is strong evidence that neglecting CSFs can lead to delayed decision-making and strongly impact project costs. Additionally, the need for late project changes impacts the other two dimensions of performance-quality and time to launch-because of the need for additional project activities, repeated tests or new tests, and the consequent delays in the delivery of the NPD phases.

The five most important CSFs can also be analyzed in the regional context in order to determine whether there are differences according to the respondents' opinions. The list of the most important CSFs at the regional level, which differ from the five most important CSFs in the overall result, is shown in Figure 7. The "Clearly defined objectives" CSF, which was $6^{\text {th }}$ in the overall ranking, is among the five most important CSFs for three regions when they are analyzed separately. These three regions are North America, Europe, and Oceania. Europe also has greater regionality with three different CSFs: "Project mission: initial clarity of objectives and general directions", "Consideration of different viewpoints during the PD phases", and "Clearly defined objectives". These three CSFs are not on the list of the top five CSFs in the overall ranking.

Figure 7. Most important CSFs at the regional level

\begin{tabular}{l|l}
\hline North America & Clearly defined objectives \\
\hline Europe & $\begin{array}{l}\text { Project mission: initial clarity of objectives and } \\
\text { general directions. } \\
\text { Consideration of different viewpoints during } \\
\text { the PD phases. } \\
\text { Clearly defined objectives. }\end{array}$ \\
\hline Asia & $\begin{array}{l}\text { Project mission: initial clarity of objectives and } \\
\text { general directions. } \\
\text { Adequate communication channels. }\end{array}$ \\
\hline Oceania & $\begin{array}{l}\text { Adequate recruitment, selection and training } \\
\text { of necessary personnel. }\end{array}$ \\
\hline
\end{tabular}

\subsection{Results and discussion of the BP questionnaire}

With regard to the respondents' geographic locations, the majority of respondents in this second phase of the study, 38.7\%, are located in South America, as shown in Figure 8.

Since most of the respondents are located in South America, the same explanations that were mentioned above for the previous CSF questionnaire are valid.

With regard to the respondent's hierarchical leadership level, the results that are obtained for this question are shown in Figure 9.
Figure 8. Geographic locations of respondents

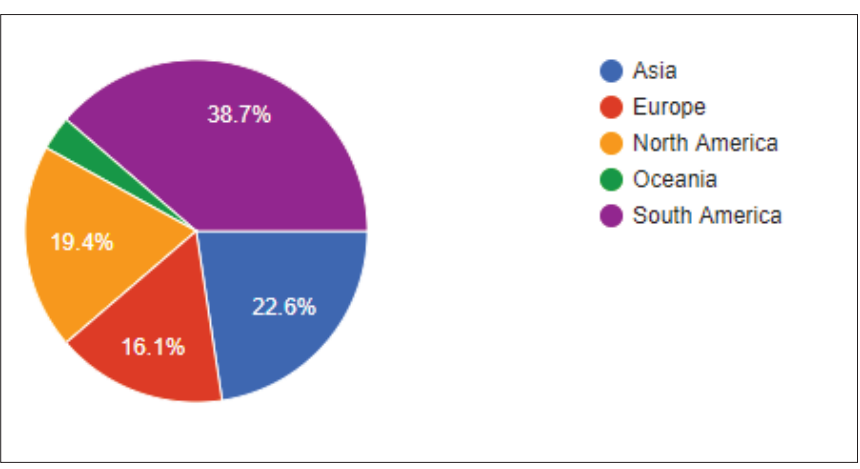

Figure 9. Hierarchical leadership levels of the respondents

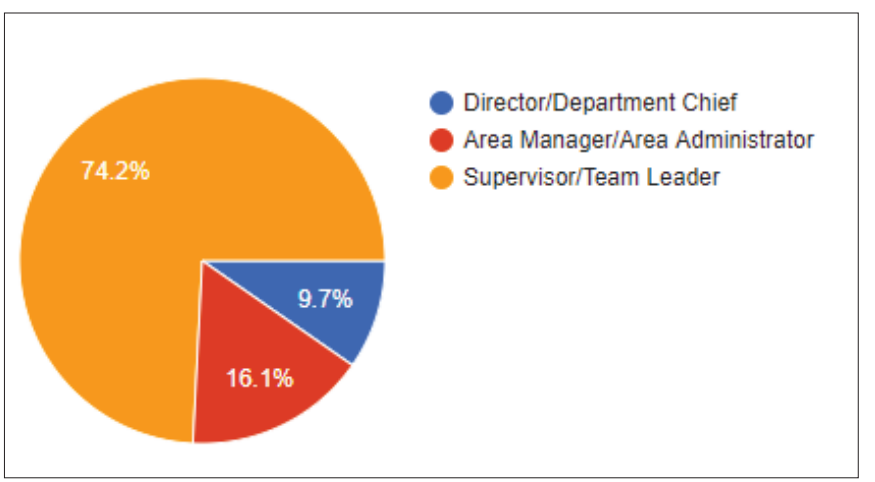

With regard to the respondents' time in a leadership position, $58.1 \%$ of the respondents have more than 6 years of leadership experience, and $19.4 \%$ have 11 or more years. With regard to their total professional experience, considering all the positions and companies in which the respondent has worked, $38.7 \%$ of the respondents had more than 20 years of experience. Again, the respondents had a high level of experience. In this second phase of the study, $80.6 \%$ of the respondents were male. The rate of female respondents was practically the same as in the previous CSF questionnaire at approximately 19\%. Therefore, the comments that were made about the low share of women in managerial positions in companies are, once again, reiterated.

The most important question on the questionnaire sought to identify the most important (single) BP for each of the five most important CSFs that were previously defined in the first phase of the study from the list of 31 BPs.

For CSF number 1, "Clear connection between projects and the company's key strategic priorities," the most important associated $\mathrm{BP}$ in the respondents' opinion was the "Use of a requirements traceability matrix to ensure that each requirement adds business value through its link to the business objectives and project objectives." This traceability matrix assists the project team since it simultaneously provides a way to track the project from its beginning to end and to structure the management of the changes, thus contributing to the project requirements being delivered. Tracking includes (but is not limited to) the following: business needs, opportunities, goals and objectives; project objectives; project scope; product design; PD; testing 
strategy and test scenarios; and high-level detailed requirements. This is emphasized in the Project Management Body of Knowledge (PMBOK) (2013) guide.

For CSF number 2, "Establish a strong business plan/solid foundation for the project," the most important associated BP in the respondents' opinion was "The company performs the necessary duties, including the following: comprehensive market research, including on customers' opinions, to determine the user's unmet and unexpressed needs and correctly define the product; a proof of concept to validate the product's concept; and value analysis to determine the economic value of the new solution for the client. The technical work proceeds in parallel and includes a complete technical assessment to identify the technological risks and failure points and an assessment of the operations and source of supplies to determine manufacturing capacity, costs and investment." A great interdepartmental effort is necessary for this BP to be carried out. This effort culminates in comprehensive business analysis and a clear recommendation to top management supporting the decision to continue with or halt the new product project (Cooper, 2011).

For CSF number 3, "Client/user engagement," the most important associated BP in the respondents' opinion was "Remain connected to the clients. Client consultation is required during both the planning phases and the final stages of product development." This client consultation must follow a logical sequence: consult the client to determine their specific needs, present the ideas/budget/schedule, and verify that the project is acceptable to the client (Pinto \& Slevin, 1988).

For CSF number 4, "Realistic expectations," the most important associated BP in the respondents' opinion was "The project outputs and results are frequently reviewed to ensure that they are in line with expectations." A project's success will be more easily measured when the results and progress are effectively monitored. To this end, there must be a common understanding and agreement among the people who are involved. The project needs to be outcome-oriented rather than activity-based (Clarke, 1999). The reality is that most large companies have several simultaneous projects. Correctly monitoring the planning and execution of the projects helps prevent delivery failures (Buys \& Stander, 2010).

For CSF number 5, "Adequate budget," the most important associated $\mathrm{BP}$ in the respondents' opinion was the "Adoption of a continuous budgeting approach, constantly comparing performance against the key indicators." Continuous budgeting is different than traditional budgeting. While the latter is based on its ability to control costs and achieve goals, the former is integrated with other control processes to have flexibility in the case of unexpected events. Continuous budgeting operates as a diagnostic control and can also be interactively used (Frow, Marginson \& Ogden, 2010). Another important point is to avoid confusing the objectives. Project success objectives are often confused with project management objectives, such as the "budget" being treated as the project's "profitability." Budget is primarily a project management item, while profitability is a project objective (Munns \& Bjeirmi, 1996).

The BP questionnaire has additional subquestions, which allow the respondent to specify other BPs that were not on the selection list. A total of sixteen other BPs were specified by the respondents, as shown in Table 3. The other BPs specified are highly important to the study's results since they reflect the reality of the NPD process of active project managers in the automotive industry.

Table 3. BPs indicated by respondents

\begin{tabular}{|c|c|}
\hline $\begin{array}{c}\text { Five most } \\
\text { important CSFs }\end{array}$ & Other BPs specified by the respondents \\
\hline $\begin{array}{l}\text { \#1) Clear } \\
\text { connection between } \\
\text { projects and the } \\
\text { company's key } \\
\text { strategic priorities }\end{array}$ & $\begin{array}{l}\text { - The project should explicitly identify which strategic priorities will contribute significantly. } \\
\text { - Another factor includes the clear definition of objectives that are directly connected to strategic } \\
\text { goals, such that everyone working on a strategic project to achieve that objective clearly understands } \\
\text { how they support the strategy in the short and long term. }\end{array}$ \\
\hline $\begin{array}{l}\text { \#2) Establish a } \\
\text { strong business } \\
\text { case/solid } \\
\text { foundation for the } \\
\quad \text { project }\end{array}$ & $\begin{array}{l}\text { - The business case should be signed by the operational units associated with the delivery - material } \\
\text { is developed to allow the business case to be explicitly identified. } \\
\text { - Sometimes, with new risks and technological uses that still cannot be quantified, the visionary } \\
\text { leadership of a top executive can also be a factor in the execution of a specific project. } \\
\text { - There is a need for "points of verification" to evaluate the project and make corrections. } \\
\text { - We also need a great leader to make the call not just on paper. }\end{array}$ \\
\hline $\begin{array}{l}\text { \#3) Client/user } \\
\text { engagement }\end{array}$ & $\begin{array}{l}\text { - The client's needs should be met - but only if this can be done lucratively. } \\
\text { - The client's voice is important for understanding the priority needs; however, some client needs } \\
\text { cannot be expressed by the client and can only be met through the specialized knowledge of the } \\
\text { project and the capabilities of the team's system. } \\
\text { - Time is critical. It is important to develop technologies and be a pioneer in the market. Loyal clients } \\
\text { appreciate leaders and consumers that encourage followers. } \\
\text { - It is necessary to identify people considered "opinion makers." People and groups that have a clear } \\
\text { understanding of the coming years and the client's desires, before the client understands what they } \\
\text { need. }\end{array}$ \\
\hline $\begin{array}{l}\text { \#4) Realistic } \\
\text { expectations }\end{array}$ & $\begin{array}{l}\text { - Periodic revision of the client's evolution/market needs in the entire development program to verify } \\
\text { the constantly changing requirements. } \\
\text { - Realistic schedule for success. } \\
\text { - Be absolutely clear about what the boss or client requires. } \\
\text { - Be absolutely clear about fixed factors }\end{array}$ \\
\hline $\begin{array}{l}\text { \#5) Adequate } \\
\text { budget }\end{array}$ & $\begin{array}{l}\text {-The budget should be optimal, not adequate. } \\
\text { - Continuous revision of the budget for the target. If an increase is necessary: justify it. }\end{array}$ \\
\hline
\end{tabular}

ISSN: 0718-2724. (http://jotmi.org) 


\section{Implications, Limitations \& Future Research}

This study seeks to contribute to product development project management in the automotive industry. It is expected that the results of this study can be used as a reference for project managers in their future projects, especially when developing products in the automotive industry, thereby preventing problems that may lead to a project's failure or cancellation. The results can serve as a foundation for future studies that are focused on product development projects in the industry. The study's assumption is confirmed by the results. The five major CSFs in the automotive industry are almost entirely different from the most important CSFs in industry in general. The need for a focused approach to CSFs is therefore reinforced. There was also evidence that was favored the confirmation of the proposed conceptual model.

The extreme importance of the FE phase in the NPD process is confirmed by the study results since the five most important CSFs belong to only two categories, "strategy" and "planning," which contain activities that are typical of the FE phase. The five most significant CSFs alone account for $29 \%$ of the total responses, showing a clear convergence of opinions.

Regarding the potential differences due to the regional context, a similarity was found among the regions in the estimated canceled projects rate. However, there are differences in the lists of the five most important CSFs for each region, with Europe being the most different in that regard.

Finally, the study's results confirm the importance of CSFs for projects, as well as the adoption of their respective associated BPs. The respondents' significant experience as project managers helps validate this confirmation. The results show that neglecting CSFs, which can lead to delayed decision-making, has a strong impact on costs.

The main limitation of this study is that it used the case study survey methodology, and the external validity of the study is therefore low. The results may have been influenced by the particularities of the NPD process and the business model of the company under study. Moreover, the rankings of the CSFs and BPs that are obtained from the questionnaire results may tend to more strongly reflect the opinions of the "Supervisor" hierarchical level since the majority of the respondents belong to this level.

Another limitation is that the research considers the CSFs and BPs that are applied in NPD solely from the perspective of project managers. Moreover, it does not quantitatively examine the relationship between meeting CSFs and performance. Only qualitative analysis was conducted here.

With regard to future studies, one recommendation is to expand the sample in order to expand the study. This can be done applying the questionnaires to the other large global companies in the automotive sector to capture the specific characteristics of their operations and NPD processes and then forming a broader list of the most important CSFs and their respective associated BPs.
There is evidence of another important CSF that is related to "blocking" project decisions in the North American region. Further study in this region is also recommended.

\section{References}

Alias, Z., Zawawi, E. M. A., Yusof, K., \& Aris, N. M. (2014). Determining critical success factors of project management practice: A conceptual framework. Procedia-Social and Behavioral Sciences, 153, 61-69.

Amason, A. (2011). Strategic management: From theory to practice. Routledge, London.

Bahia, L. D., \& Domingues, E. P. (2010). Estrutura de inovações na indústria automobilística brasileira No. 1472). Texto para Discussão, Instituto de Pesquisa Econômica Aplicada (IPEA). Retrieved from https://www.econstor.eu/bitstream/10419/91381/1/626406919.pdf on $06 / 20 / 2019$.

Baker, B. N., Murphy, D. C., \& Fisher, D. (1997). Factors affecting project success. Project management handbook, 902-919. Van Nostrand Reinhold Co, New York

Baldry, D. (1998). The evaluation of risk management in public sector capital projects. International Journal of Project Management, 16 (1), 35-41.

Bear, D. (1995). Risk management in information systems development-a case study. Engineering Management Journal, 5(2), 63-65.

Belassi, W., \& Tukel, O. I. (1996). A new framework for determining critical success/failure factors in projects. International journal of project management, 14(3), 141-151.

Bradley, G. (2010). Benefit Realisation Management, First ed. MPG Books Group, UK, Farnham.

Breese, R. (2012). Benefits realisation management: Panacea or false dawn?. International Journal of Project Management, 30(3), 341-351.

Buttrick, R., (1997). The Project Workout: a Toolkit for Reaping the Rewards From all Your Business Projects, First ed. Financial Times Management, London.

Buys, A. J., \& Stander, M. J. (2010). Linking projects to business strategy through project portfolio management. South African Journal of Industrial Engineering, 21(1), 59-68.

Carvalho, M. M. D., \& Rabechini Junior, R. (2015). Impact of risk management on project performance: the importance of soft skills. International Journal of Production Research, 53(2), 321-340.

Cash, C. H., \& Fox II, R. (1992). Elements of successful project management. Journal of Systems Management, 43(9), 10.

Chan, A. P., Scott, D., \& Chan, A. P. (2004). Factors affecting the success of a construction project. Journal of construction engineering and management, 130(1), 153-155. 
Chittenden, J., \& Van Bon, J. (2006). Programme management based on MSP: a management guide ( $1^{\text {st }}$ ed.) Van Haren Publishing, Zaltbommel.

Clarke, A. (1999). A practical use of key success factors to improve the effectiveness of project management. International journal of project management, 17(3), 139-145.

Clark, K. B., \& Wheelwright, S. C. (1993) Managing new product development-text and cases. Harvard Business School. New York: Free Press.

Cooke-Davies, T. (2002) The "real" success factors on projects. International journal of project management, 20(3), 185-190.

Cooper, R. G. (2011): Perspective: The innovation dilemma: How to innovate when the market is mature. Journal of Product Innovation Management, 28(s1), 2-27.

Cooper, R. G., \& Kleinschmidt, E. J. (2007). Winning businesses in product development: The critical success factors. Research-Technology Management, 50(3), 52-66.

Desmond, C. (2017). Project management tools-A few basic tools. IEEE Engineering Management Review, 45(2), 25-26.

De Souza, P., \& Lunkes, R. J. (2016). Capital budgeting practices by large Brazilian companies. Contaduría y Administración, 61(3), 514-534.

Dinu, A. M. (2016). Project Risk Management-Reasons Why Projects Fail. Quality-Access to Success, Supplement 17, S3. Pp.208.

Dupont, D. H., \& Eskerod, P. (2016): Enhancing project benefit realization through integration of line managers as project benefit managers. International Journal of Project Management, 34(4), 779-788.

Dvir, D., Lipovetsky, S., Shenhar, A., \& Tishler, A. (1998): In search of project classification: a non-universal approach to project success factors. Research policy, 27(9), 915-935.

Fortune, J., \& White, D. (2006): Framing of project critical success factors by a systems model. International journal of project management, 24(1), 53-65.

Frow, N., Marginson, D., \& Ogden, S. (2010): “Continuous” budgeting: Reconciling budget flexibility with budgetary control. Accounting, Organizations and Society, 35(4), 444-461.

Frese, R., \& Sauter, V. (2003): Project success and failure: What is success, what is failure, and how can you improve your odds for success. Retrieved June 20th,2019 from http://www.umsl.edu .

Gal, Y., \& Hadas, E. (2015): Why projects fail: Knowledge worker and the reward effect. Journal of the Knowledge Economy, 6(4), 968-977. Gil, A. C. (2008): Como elaborar projetos de pesquisa, 6a ed. São Paulo: Atlas.
Gino, F., \& Pisano, G. (2008): Toward a theory of behavioral operations. Manufacturing \& Service Operations Management, 10(4), 676-691.

Hughes, M. W. (1986): Why projects fail-The effects of ignoring the obvious. Industrial Engineering, 18(4), 14.

Jenner, S. (2010): Transforming government and public services. Gower, Farnham.

Jordan, G., Lee, I., \& Cawsey, G. (1988): Learning from experience: a report on the arrangements for managing major projects in the Procurement Executive. HM Stationery Office, London.

Kasser, J. E., \& Williams, V. R. (1998): What do you mean you can't tell me if my project is in trouble?. In First European Conference on Software Metrics (FESMA 98).

Kornish, L. J., \& Hutchison-Krupat, J. (2017): Research on idea generation and selection: Implications for management of technology. Production and Operations Management, 26(4), 633-651.

Levine, R. (2006): Finance and Growth: Theory and Evidence. Eds. Handbook of Economic Growth, P. Aghion and S. Durlauf, Amsterdam: North-Holland.

Lindhard, S., \& Larsen, J. K. (2016): Identifying the key process factors affecting project performance. Engineering, Construction and Architectural Management, 23(5), 657-673.

Milosevic, D., \& Patanakul, P. (2005): Standardized project management may increase development projects success. International journal of project management, 23(3), 181-192.

Müller, R., \& Jugdev, K. (2012): Critical success factors in projects. International Journal of Managing Projects in Business, 5(4), 757-775.

Munns, A. K., \& Bjeirmi, B. F. (1996): The role of project management in achieving project success. International journal of project management, 14(2), 81-87.

Ogunde, A., Olaolu, O., Afolabi, A. O., Owolabi, J., \& Ojelabi, R. A. (2017): Challenges confronting construction project management system for sustainable construction in developing countries: Professionals perspectives (a case study of Nigeria). Journal of Building Performance, 8(1), 1-11.

Poon, P., \& Wagner, C. (2001): Critical success factors revisited: success and failure cases of information systems for senior executives. Decision support systems, 30(4), 393-418.

Pinto, J. K., \& Kharbanda, O. P. (1995): Lessons for an accidental profession. Business Horizons, 38(2), 41-50.

Pinto, J.K. \& Slevin D.P. (1988): Critical success factors in effective project implementation. In: CLELAND, D. I.; KING, W.R. Project management handbook. New York: Van Nostrand 
Pinto, J. K., \& Slevin, D. P. (1989): Critical success factors in R\&D projects. Research-technology management, 32(1), 31-35.

Pozin, M. A. A., Nawi, M. N. M., \& Romle, A. R. (2016): Effectiveness of virtual team for improving communication breakdown in IBS project delivery process. International Journal of Supply Chain Management, 5(4), 121-130.

PMBOK Guide (2013): Project Management Body of Knowledge, 3rd ed., Project Management Institute, Newtown Square, PA.

Reed, C., Botts, M., Davidson, J., \& Percivall, G. (2007): Ogc ${ }^{\circledR}$ sensor web enablement: overview and high level architecture. In 2007 IEEE Autotestcon (pp. 372-380). IEEE.

Repenning, N. P., Gonçalves, P., \& Black, L. J. (2001); Past the tipping point: the persistence of firefighting in product development. California Management Review, 43(4), 44-63.

Repenning, N. P. (2001): Understanding fire fighting in new product development. Journal of Product Innovation Management, 18(5), 285-300.

Rockart, J. F. (1982): The Changing Role of the Information Systems Executive: A Critical Success Factors Perspective. Sloan Management Review (pre-1986), 24(1), 3.

Roy, R., Colmer, S., \& Griggs, T. (2005): Estimating the cost of a new technology intensive automotive product: A case study approach. International Journal of Production Economics, 97(2), 210-226.

Sandahl, G., \& Sjögren, S. (2003): Capital budgeting methods among Sweden's largest groups of companies. The state of the art and a comparison with earlier studies. International journal of production economics, 84(1), 51-69.

Sauser, B. J., Reilly, R. R., \& Shenhar, A. J. (2009): Why projects fail? How contingency theory can provide new insights-A comparative analysis of NASA's Mars Climate Orbiter loss. International Journal of Project Management, 27(7), 665-679.

Serra, C. E. M., \& Kunc, M. (2015): Benefits realisation management and its influence on project success and on the execution of business strategies. International Journal of Project Management, 33(1), 53-66.

Spinelli, D. (1997): Keys to success in management projects. Network World, 4(14).
Stanley, R., \& Uden, L. (2013): Why projects fail, from the perspective of service science. In 7 th international conference on knowledge management in organizations: service and cloud computing (pp. 421-429). Springer, Berlin, Heidelberg.

Thiry, M. (2002): Combining value and project management into an effective programme management model. International journal of project management, 20(3), 221-227.

Thite, M. (2000): Leadership styles in information technology projects. International Journal of Project Management, 18(4), 235-241.

Turner, J. R. (1999): The handbook of project-based management (Vol. 2). London: McGraw-Hill.

Turner, J. R. (2004): Managing web projects: the management of large projects and programmes for web-space delivery. Gower Publishing, Ltd. Aldershot.

Thomke, S., \& Von Hippel, E. (2002): Customers as innovators: a new way to create value. Harvard business review, 80(4), 74-85.

Musawir, A., Serra, C. E. M., Zwikael, O., \& Ali, I. (2017): Project governance, benefit management, and project success: Towards a framework for supporting organizational strategy implementation. International Journal of Project Management, 35(8), 1658 1672 .

Wateridge, J. (1995): IT projects: a basis for success. International journal of project management, 13(3), 169-172.

Westerveld, E. (2003): The Project Excellence Model ${ }^{\circledR}$ : linking success criteria and critical success factors. International Journal of project management, 21(6), 411-418.

Weir S. Designing and managing successful projects. http://www.jws. net/weir/design.html [accessed september 2019].

Whittaker, B. (1999): What went wrong? Unsuccessful information technology projects. Information Management \& Computer Security, 7(1), 23-30.

Yeo, K. T. (2002): Critical failure factors in information system projects. International journal of project management, 20(3), 241-246. 
